\title{
EFFECT OF FREQUENT BLOOD DONATION ON IRON STATUS OF BLOOD DONORS IN BURDWAN, WEST BENGAL, INDIA
}

\author{
Datta Subinay, *Pal Mrinal, Ghosh Chinmoy \\ Department of Biochemistry, Burdwan Medical College, Burdwan, West Bengal, India-713104 \\ *Corresponding author: Email: mrinalpal77@rediffmail.com; Mob: 09007593545
}

\begin{abstract}
Background: Anaemia was reported as one of the most important reasons for blood donor deferral and very frequent blood donation will have a negative impact on the health of the donor and quality of donated blood products.

Aim: The purpose of the study was to assess the influence of frequency of blood donation on iron stores of the donors. Method: The study population were divided into five groups. Forty one were first time (control group), Thirty-eight were $\leq 10$ times, thirty-two were 11-20 times, twenty seven were 21-50 times and seventeen were $>50$ time blood donors. Pre-donation blood haemoglobin and serum ferritin assessment was done in each individual.

Result: Serum ferritin of $<10$ times/4years were not significantly reduced than first time healthy donors but $>10$ times/4years donors onwards iron status were significantly reduced $(p>0.001)$ progressively as frequency of donation increased and individuals potentially at risk for developing iron deficiency.

Conclusion: It is the conclusion of this study that increased frequency of blood donation reduced the iron stores of donors. Therefore, volunteers who undergo repeated blood donation and professional donors should be advised on eating balanced diet as well as receive nutritional care especially in terms of iron supplementation.

Key Words: Blood donation, Serum ferritin, Iron deficiency.
\end{abstract}

\section{INTRODUCTION}

Voluntary unpaid blood donation is a humanitarian act towards the sick by the healthy. No transfusion service can survive without blood donors. A donor generally donates approximately $450 \mathrm{ml}$ of blood at the time of donation. If $450 \mathrm{ml}$ of blood is taken in a donation men lose $242 \pm 17$ $\mathrm{mg}$ and women lose $217 \pm 11 \mathrm{mg}$ of iron. ${ }^{1}$ Hence adequate iron stores are very important in maintenance of the donor's health. ${ }^{2}$ A healthy individual can donate blood up to four times a year that means a person needs approximately 3 months to replenish iron stores ${ }^{3,4}$. But professional donors who are desperate to support their large families and to cover their personal needs will donate blood as frequent as possible. To collect as much income as they can, they will go from one blood bank to the other, using fictitious names and false identification. Many have learned how to disguise needle marks and chemical stigma. As a result they donate blood at a rate that is beyond the ability of their body to compensate. So, the present study was aimed to assess the influence of frequency of blood donation on iron status of blood donors by assessing hemoglobin which is simplest technique to identify anemic donors and serum ferritin which reflect body iron stores ${ }^{5}$.

\section{MATERIAL AND METHODS}

\section{Study area}

The present study was conducted in the department of Biochemistry with the collaboration of Blood Bank of Burdwan Medical College and Hospital, Burdwan, West Bengal, India.

\section{Selection of subjects}

This prospective and observational study was performed between June 2009 and August 2013. During these 4 years a total of 155 subjects aged between 18 and 60 years, who donated blood to the Blood Bank, were selected from 700 blood donors by random sampling method for this cross sectional study. The inclusion criteria are that they must be seronegative for Human Immunodeficiency Virus (HIV 1\&2), hepatitis B \& C and Syphilis. The exclusion criteria were use of iron supplements, pregnancy, lactation, donation elsewhere (outside them registering organizations) or a major trauma/surgery in the last three months.

Donors were divided into five donor groups: Group I: ( $\mathrm{n}=$ 41) who were donating for the first time and not suffering from anaemia, these individuals, thus represented a sample of healthy population in this region. Group II: $(n=38)$, who had donated $\leq 10$ times. Group III: $(\mathrm{n}=32)$, who were donated 11-20 times. Group IV: $(\mathrm{n}=27)$ who had donated $21-50$ times. Group V: $(\mathrm{n}=17)$, who were donated > 50 times in last 4 years. The selected donors were asked specific questions as per donor questionnaire such as age at first donation, total number of life time donations, number of donations within previous one year, interval between donations, date of last donation/previous donation, reason for donating blood, dietary history. The proposal of this study was approved by the Ethics Committee of Burdwan Medical College, West Bengal. Written consent for blood donation and blood testing was taken from each donor.

\section{Anthropometric measurements}

Weight and height measurements were obtained, using standardized technique ${ }^{6}$. BMI was calculated as the weight in kilograms divided by the square of height in meters. Body mass index (BMI) was calculated as the weight $(\mathrm{kg})$ divided by the square of height $\left(\mathrm{m}^{2}\right)$, and was categorized as underweight (BMI < 18.5), normal (BMI 
18.5-24.99), overweight (BMI 25.0-29.99), and obese (BMI 30.0 or more) according to the current World Health Organization (WHO) classification.

\section{Collection of samples}

Five milliters of venous blood sample was collected by a clean venepuncture from donors. $2 \mathrm{mls}$ of blood was delivered into potassium Ethylene Diamine Tetra Acetic Acid (K2EDTA) bottle containing $4 \mathrm{mg}$ of the anticoagulant for the analysis of haemoglobin. Another $3 \mathrm{ml}$ of blood were allowed to coagulate at room temperature for 30-45 min, followed by centrifugation at $2500 \mathrm{Xg}$ for $5 \mathrm{~min}$. All serum samples were stored at $-70^{\circ} \mathrm{C}$ and kept under these conditions until chemical analysis was performed.

\section{Laboratory investigation}

Pre-donation haemoglobin assessment was done using Beckman 890 counter. The serum used for analysis of ferritin by using enzyme-linked immunoassay (ELISA) kit supplied by . Intra-assay CV\% and inter-assay CV\% was 3.4 and 3.5. Iron stores were considered depleted at serum ferritin values $<15 \mathrm{mg} / \mathrm{l}$, reduced at values between $15-30$ $\mathrm{mg} / \mathrm{l}$, and normal or replete at values from $31-300 \mathrm{mg} / \mathrm{l}$, and increased at values beyond $300 \mathrm{mg} / \mathrm{l}$. Iron deficiency anaemia was considered present when serum ferritin was $<12 \mathrm{mg} / \mathrm{l}^{7}$.

\section{Statistical Analysis}

The data for biochemical analysis was subjected to standard statistical analysis using the Statistical Package for Social Science (SPSS) 11.5 software for windows.

\section{Personal profile and clinical details of Group I, II, III,} IV and $\mathrm{V}$ blood donors in the study

Selected characteristics of the blood donors of the study groups as shown in the Table 1

Table 1: Personal profiles and clinical parameters of the blood donors in the study under the study

\begin{tabular}{|c|c|c|c|c|c|c|}
\hline Variables & $\begin{array}{l}\text { Group I } \\
\text { 1st Time Donors } \\
(\mathbf{n}=\mathbf{4 1})\end{array}$ & $\begin{array}{l}\text { Group II } \\
\leq 10 \text { Donors } \\
(\mathbf{n}=38)\end{array}$ & $\begin{array}{l}\text { Group III } \\
\text { 11-20 Donors } \\
(\mathbf{n}=32)\end{array}$ & $\begin{array}{l}\text { Group IV } \\
\text { 21-50 Donors } \\
(n=27)\end{array}$ & $\begin{array}{l}\text { Group V >50 } \\
\text { Donors } \\
(\mathbf{n}=\mathbf{1 7})\end{array}$ & p value \\
\hline Age (years) & $34.53 \pm 10.64$ & $32.18 \pm 8.39$ & $38.04 \pm 11.14$ & $35.65 \pm 6.61$ & $39.58 \pm 7.85$ & $>0.05$ \\
\hline $\begin{array}{l}\text { Sex } \\
\text { Male } \\
\text { Female }\end{array}$ & $\begin{array}{l}29(70.73) \\
12(29.27)\end{array}$ & $\begin{array}{l}31(81.58) \\
7(18.42)\end{array}$ & $\begin{array}{l}24(75) \\
8(25)\end{array}$ & $\begin{array}{l}21(77.78) \\
6(22.22)\end{array}$ & $\begin{array}{l}16(94.12) \\
1(5.88)\end{array}$ & \\
\hline $\begin{array}{l}\text { Types of donor } \\
\text { Volunteer } \\
\text { Professional }\end{array}$ & $\begin{array}{l}41(100) \\
0\end{array}$ & $\begin{array}{l}38(100) \\
0\end{array}$ & $\begin{array}{l}9(28.12) \\
23(71.88)\end{array}$ & $\begin{array}{l}1(3.7) \\
26(96.3)\end{array}$ & $\begin{array}{l}0 \\
17(100)\end{array}$ & \\
\hline $\begin{array}{l}\text { BMI } \\
<18.5 \\
18.5-24.9 \\
25-30 \\
>30\end{array}$ & $\begin{array}{l}0(0) \\
27(65.85) \\
13(31.7) \\
1(2.44)\end{array}$ & $\begin{array}{l}2(5.26) \\
21(55.26) \\
13(34.21) \\
2(5.26)\end{array}$ & $\begin{array}{l}9(28.12) \\
17(53.12) \\
4(12.5) \\
2(6.25)\end{array}$ & $\begin{array}{l}12(44.44) \\
8(29.63) \\
2(7.41) \\
5(18.52)\end{array}$ & $\begin{array}{l}11(64.71) \\
6(35.29) \\
0(0) \\
0(0)\end{array}$ & \\
\hline
\end{tabular}

Data are expressed as numbers (group percentages in parentheses) for categorical variables and mean values \pm SD for continuous variables; $n=$ number of cases; $p>0.05$ is considered statistically not significant; $p<0.05$ is significant.

Comparison of the serum ferritin and haemoglobin level between different groups

To compare the serum ferritin level between the groups Analysis of variance (ANOVA) univariate test followed by a Tukeye Kramer posthoc test was performed and it was found that although the mean serum ferritin levels in Group II $(71.21 \mathrm{ng} / \mathrm{ml})$ were not significantly different from those of the control population, average ferritin levels further decreased with increasing frequency of blood donation. Indeed, from Group III onwards, ferritin levels differed significantly from those of healthy subjects (43.53ng/ml, 11.41ng/ml and 8.88ng/ml for Group III, IV and $\mathrm{V}$, respectively; $\mathrm{p}<0.0001$; figure 3 ). Mean ferritin levels were almost $61 \%$ lower in patients with Group V compared with controls (Table 2; figure 1). But if blood haemoglobin level was considered, haemoglobin concentrations of only Group V donors were significantly decreased than normal controls (Table 2).

Table 2: Comparison between concentrations of serum ferritin and blood haemoglobin of groups II, III, IV and V with Group I of study population

\begin{tabular}{|l|c|c|c|c|c|}
\hline Parameters & Group I & Group II & Group III & Group IV & Group V \\
\hline Concentration of serum & $73.17073 \pm$ & $71.21053 \pm 15.091$ & $43.53125 \pm$ & $11.40741 \pm$ & $8.882353 \pm$ \\
ferritin $(\mu \mathrm{g} / \mathrm{L})$ & 15.82388 & & $30.85239^{*}$ & $8.793613^{*}$ & $1.49509^{*}$ \\
\hline $\begin{array}{l}\text { Blood haemoglobin } \\
\text { concentration }(\mathrm{gm} / \mathrm{dl})\end{array}$ & $13.5 \pm 1.3$ & $13.3 \pm 2.0$ & $12.6 \pm 1.9$ & $11.9 \pm 1.6$ & $9.6 \pm 1.8^{*}$ \\
\hline
\end{tabular}




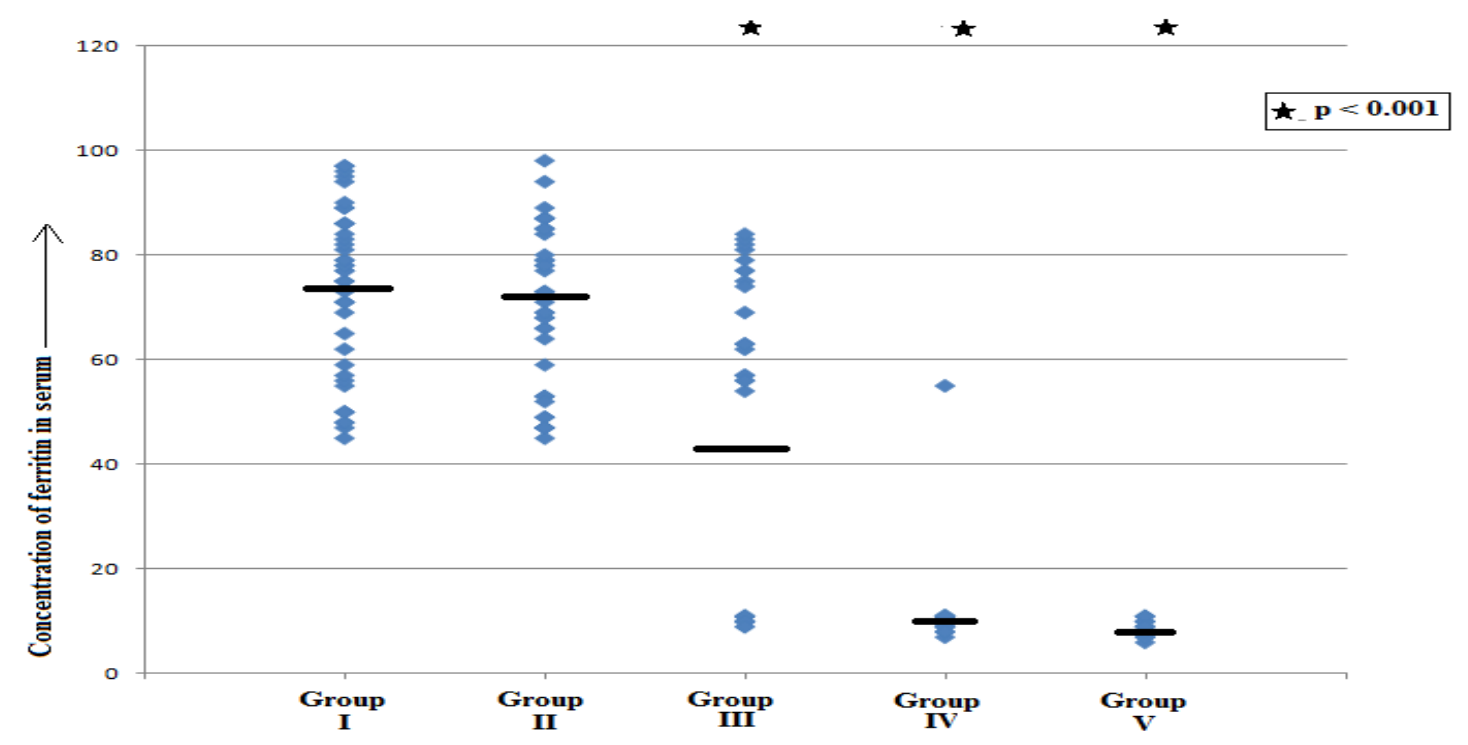

Figure 1: Plot showing serum ferritin levels in different groups of blood donors in the study. An analysis of variance (ANOVA) univariate test followed by a Tukeye Kramer posthoc test for testing multiple groups was used to calculate significances. Asterisks indicate $\mathrm{p}<0.0001$

Frequency of iron deficient donors among the groups of the study

Stratification of five Subgroups - that is, subjects deficient iron storage subjects $(<12 \mathrm{ng} / \mathrm{ml})$ and participants with normal serum ferritin levels - revealed that none of the subjects of group II exhibited iron deficiency, whereas 65.62 and $96.3 \%$, respectively, of the donors with group III, IV and as many as $100 \%$ of group V donors were deficient for iron (Table 3; figure 2). Overall, these data clearly indicate that reduced iron levels are correlated with number of blood donation.

Table 3: Frequency subjects of deficient iron storage based upon serum ferritin concentration $<12 \mathrm{ng} / \mathrm{ml}$

\begin{tabular}{|l|l|}
\hline Study groups & Deficient iron storage subjects \\
\hline Group I & $0(0)$ \\
\hline Group II & $0(0)$ \\
\hline Group III & $21(65.62)$ \\
\hline Group IV & $26(96.3)$ \\
\hline Group V & $17(100)$ \\
\hline
\end{tabular}

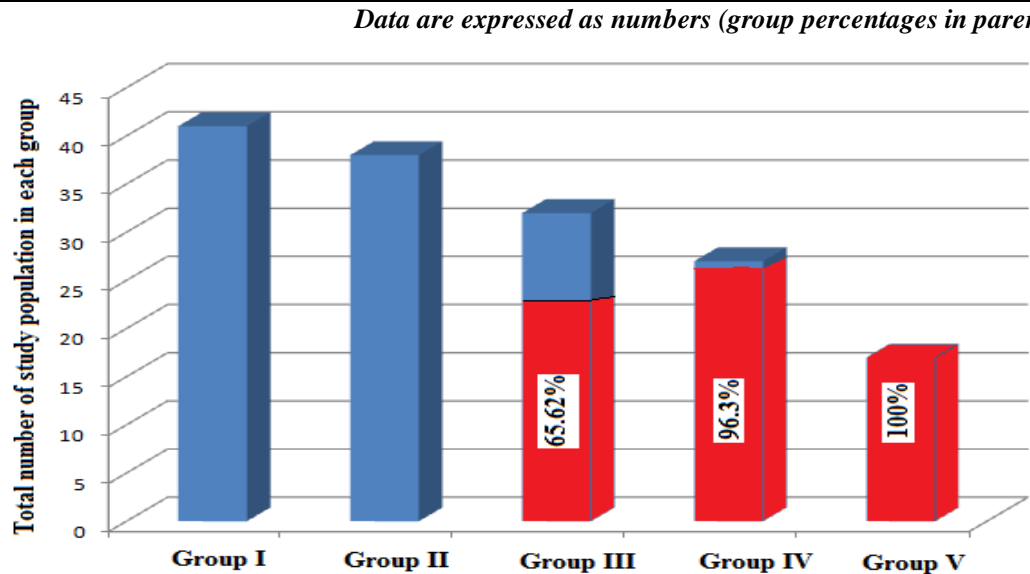

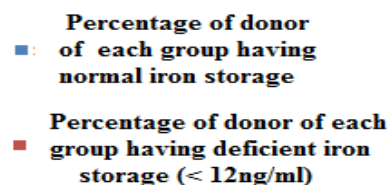

storage $(<12 \mathrm{ng} / \mathrm{ml})$

Fig 2: Percentage of blood donor having normal serum ferritin levels (Blue) and deficient serum levels $<12 \mathrm{ng} / \mathrm{ml}$ (Red)

\section{DISCUSSION}

Accident victims, people undergoing surgery and patients receiving treatment for leukaemia, cancer or other diseases, such as sickle cell disease and thalassaemia, all utilized blood. As demand of blood products rapidly increasing and only human being can fulfil the huge demand for blood, more and more donor are required. For this reason, the nutritional status of blood donors receives little attention. While some blood banks measure the blood pressure of the donors, their body is rarely weighed. Underweight donor who does not meet his caloric requirements is very likely to suffer from nutritional deficiencies. So, the present study was conducted to design to assess iron stores in blood donors and the effect of frequency of blood donation in the development of iron deficiency. It was found that serum ferritin of first-time healthy and $\leq 10$ times in 4 years donors in this locality did not differ significantly suggesting appropriate frequency of blood donation was maintained as none of the donor was 
professional donor. The iron related parameters of $>10$ times in 4 year donors were significantly reduced when compared with first time donors. The implication of this finding is that $>10$ times/4years time donation, the donors starts developing anaemia due to depletion of iron stores as most of the blood donors were professional donors. The results of this study show that professional blood donors were mostly illiterate or with limited education, came from large families and had a very limited income. Their only motive for blood donation is financial. The better educated volunteer donors with higher income donate best quality blood to meet the need of a friend, a relative or for humanitarian reasons and have very low prevalence of blood transmitted diseases. The nutritional status of the blood donor is one of the important factors determining the quality of the donated blood. A well nourished donor free from infectious and non-communicable diseases will donate the best quality blood. The nutritional conditions of professional blood donors receive little attention. When malnutrition was coupled with very frequent blood donation, iron deficiency anaemia is an expected outcome just like our present study. This was confirmed by one previous study ${ }^{8}$ which postulated that chronic iron deficiency is a well-recognized complication of regular blood donation. Another recent study ${ }^{9}$ have explained that blood donation leads to substantial iron loss, as about 0.5 $\mathrm{mg}$ iron is lost per each millimetre of blood donated. If not compensated for efficiently, the iron loss may eventually lead to anaemia. Another reason for iron deficiency in donors with repeated donations is that the iron demands increase with number of annual blood donations ${ }^{10}$. Even though the absorption of nutritional iron among donors is much more efficient than non-donors, a donation frequency of $>4$ units per year cannot be compensated by iron absorption and results in an iron deficiency ${ }^{10-12}$. Another important finding was that though the quality of the donated blood is evaluated by measuring hemoglobin concentration as it is the simplest technique to identify anemic donors, haemoglobin levels did not significantly reduced up to 50 times donor/4 years group though depletion of iron store had started from $>10$ times donor in 4 years as observed in some previous studies ${ }^{13-15}$. So, donors potentially at risk for developing iron deficiency anaemia can be detected only by estimation of ferritin. Whatever the method of detection, anaemic donor will donate inferior quality blood to the needy patient. On the other hand repeated blood donation will have a negative impact on the health of the donor. This is made obvious by the iron stores of very frequent blood donors are no longer quite fit to donate blood.

\section{CONCLUSION}

The findings of this work have suggested that efficient calls for a public education of all, particularly the donors of donating more than 4 times in a year especially in the third world countries like our country where we depend mostly on commercial donors for blood donation. Considering this observation, we may suggest that more frequent donations should be discouraged as the quality of such blood may not be satisfactory for use. Again, this will also help to prevent the donors from developing anaemia due to blood donation. More sensitive indicators such as ferritin which reflect body iron stores are must be measured by each and every blood bank before donation of blood products by every donor as anaemic donors who came to the blood bank without knowing that they were anaemic. Donors who have donated twice should be placed on iron supplement to prevent iron stores depletion. Moreover, the importance of eating balanced diet by the donors should always be emphasized as they visit for donation. Proper and effective records of blood donors indicating the date of the most recent donation must be kept and exchanged between blood banks.

\section{ACKNOWLEDGEMENT}

Authors are thankful to Mr. Karthik Basu, Naba Kumar Das and Chandi Charan Das of Burdwan Medical College and Hospital for technical support.

\section{REFERENCES}

1. Simon TL. Iron, iron everywhere but not enough to donate Transfusion 2002; 42: 664-5.

2. Hewitt space PE, Wagstaff W. ABC of Transfusion. Bri Med J. 1999; 299: 1391 - 1394.

3. Boulton F, Collis D, Inskip H, Paes H, Garlick M. A study of the iron and HFE status of blood donors, including a group who failed the initial screening for anemia. Br J Haematol 2000; 108 : 434-9.

4. Skikne BS, Lynch S, Borek I, Cook J. Iron and blood donation. Cli. Haematol. 1984;13:271-287.

5. Ezzat S. A comparative study of the nutritional status of volunteer and professional male blood donors. International Journal of Food, Nutrition and Public Health, 2011;4(2):177-183.

6. Deepa M, Pradeepa R, Rema M, Mohan A, Deepa R, Shanthi Rani S, Mohan V. The Chennai Urban Rural Epidemiology Study ( CURES) : Study design and Methodolgy ( Urban component ) CURES -1 J. Assoc. Physicians India 2003;51: 863-870.

7. Milman N, Kirchoff M. Influence of blood donation on iron stores assessed by serum ferritin and hemoglobin in a population survey of 1433 Danish males. Eur J Hematol 1991; 47 : 134-9.

8. Mittal R, Marwaha N, Basu S, Mohan H, Ravi Kumar A Evaluation of iron stores in blood donors by serum ferritin. Indian J Med Res 2006;124: 641-6.

9. Djalali M, Tirang RN, Bateni J, Siassi F. The effect of repeated blood donations on the iron status of Iranian blooddonors attending the Iranian blood transfusion organization. Int. J. Nutr. Res 2006;76 (3): 132-137.

10. Simon TL, Garry PJ, Hooper EM. Iron stores in blood donors. JAMA 1981; $245: 2038-43$.

11. Garry PJ, Koehler KM, Simon TL. Iron stores and iron absorption: effects of repeated blood donations. Am J Clin Nutr 1995; $62: 611-20$.

12. Borch-Johnesen B, Halvorsen R, Stenberg V, Flesland O, Mowinckel P. The effect of daily low-dose iron supplements in female blood donors with depleted iron stores: comparison with female non-donors. Scand J Clin Lab Invest 1993; 53 : 789-91.

13. Milman N, Sondergard M. Iron stores in male donors evaluated by serum ferritin. Transfusion 1984; 24 : 464-8.

14. Alvarez-Ossorio L, Kirchner H, Kluter H, Schlenke P. Low ferritin levels indicate the need for iron supplementation: strategy to minimize iron-depletion in regular blood donors. Transfus Med 2000; 10: 107-12.

15. Akarsu S, Kilic M, Yilmaz E, Aydin M, Taskin E, Aygun AD. Frequency of hypoferritinemia, iron deficiency and iron deficiency anemia in outpatients. Acta Haematol 2006; 116: 4650 